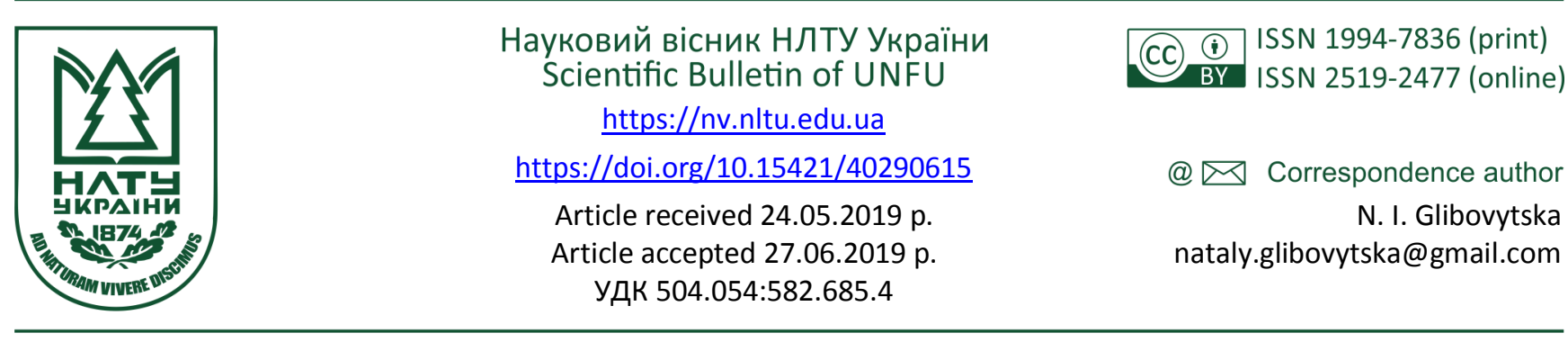

Н. І. Глібовицька, Л. В. Плаксій

Івано-Франківський національний технічний університет нафти і газу, м. Івано-Франківськ, Украӥна

\title{
ЕФЕКТИВНІСТЬ ПОГЛИНАННЯ НАФТИ СОРБЕНТАМИ ПРИРОДНОГО ТА ШТУЧНОГО ПОХОДЖЕННЯ
}

\begin{abstract}
Розглянуто глобальну екологічну проблему контамінації нафтою водних ресурсів та методи боротьби з нею. Досліджено ефективність простих і доступних способів очищення забрудненої нафтою води. Виявлено економічну вигоду від застосування сорбуючого методу боротьби з проблемою порівняно з механічним та диспергуючим методами. Сорбуючий метод $\epsilon$ найменш економічно затратний та дуже зручний у застосуванні, оскільки передбачає використання широкого спектра сорбентів нафти. Перспективність цього методу полягає у доступності деяких природних і штучних матеріалів, які можна використати як сорбенти нафти. Проаналізовано практичне значення, переваги та недоліки природних і штучних сорбентів нафти, які широко використовують у різних галузях промисловості та національного господарства. Виявлено максимальну поглинальну здатність бавовни як природного матеріалу, який швидко абсорбує компоненти нафти та не потребує використання додаткових ресурсів для боротьби з контамінацією води. З'ясовано, що природний абсорбент чорне вугілля малоефективне порівняно з іншими методами очищення води від нафти та потребує тривалого часу та додаткових уловлювачів забруднення, що є економічно невигідно. Синтетичний полімер пінопласт і біле вугілля поглинають нафту за короткий час, однак в останньому випадку на поверхні води залишаються незначні плями. Виявлено, що не вся частина білого вугілля прореагувала 3 нафтовою масою, а випала в осад. Тому за ефективністю поглинання нафти природними та синтетичними матеріалами можна виділити такий ряд досліджених матеріалів: чорне вугілля $\rightarrow$ пінопласт $\rightarrow$ біле вугілля $\rightarrow$ бавовна.
\end{abstract}

Ключові слова: нафта; забруднення; водні ресурси; очищення; методи; сорбенти.

Вступ. Нафта є одним з основних і найнебезпечніших забруднювачів водних екосистем, що призводить до загибелі їх мешканців. Щороку у водні простори морів та океанів надходить понад 3 млн т нафти внаслідок аварій на бурових установках і платформах, магістральних газо- і нафтопроводах. Будівельні та технологічні дефекти та корозія трубопроводів призводять до прориву і руйнування обладнання 3 наступним аварійним витоком нафти (Plaksii, 2016; Tsibulnikova, 2015).

На поверхні води нафта може утворювати плівку, перебувати у формі розчинених або емульгованих у воді речовин, або осідати на дно водойми. Токсичний вплив компонентів нафти на водних мешканців призводить до їх загибелі та отрусння організмів, які знаходяться на вищих трофічних рівнях харчової піраміди. Ураження кровоносної, нервової систем людини спричиняють низькомолекулярні аліфатичні, нафтенові, ароматичні вуглеводні, а також важкі метали наявні у нафтi (Kablov \& Ioschenko, 2004; Pogharnitskaya, 2016; Vladimirov, 2014).

Найвищі рівні забруднення нафтопродуктами зафіксовано у Середземному та Балтійському морях, що становить, відповідно, 17 та $14 \%$ від усього забруднення Світового океану. В Україні, де щороку у водні екосистеми потрапляє понад 0,5 млн т нафти, використовують таку градацію для визначення маси нафти на поверхні води (табл. 1) (Maksymov et al., 2004).

Табл. 1. Візуальні показники для визначення маси нафти на поверхні води

\begin{tabular}{|c|l|c|}
\hline \multicolumn{1}{|c|}{$\begin{array}{l}\text { Визначення маси нафти на 1 м² водної поверхні } \\
\text { за зовнішнім виглядом нафтової плівки (середні } \\
\text { дані) }\end{array}$} & $\begin{array}{c}\text { Маса нафти } \\
\text { на 1 м² вод- } \\
\text { ної пов, г }\end{array}$ \\
\hline 1 & $\begin{array}{l}\text { Чиста водна поверхня без ознак забарвлення } \\
\text { за різноманітних умов освітлення }\end{array}$ & 0 \\
\hline 2 & $\begin{array}{l}\text { Відсутність плівки і плям, окремі райдужні } \\
\text { смуги, які видно за найсприятливіших умов і } \\
\text { спокійного стану водної поверхні }\end{array}$ & 0,1 \\
\hline & $\begin{array}{l}\text { Окремі плями та сірі плівки сріблястого } \\
\text { кольору на поверхні води, які видно за спо- } \\
\text { кійного стану водної поверхні, поява перших } \\
\text { ознак забарвлення }\end{array}$ & 0,2 \\
\hline 4 & $\begin{array}{l}\text { Плями і плівки з яскравими кольоровими } \\
\text { смугами, які видно за незначного хвилювання }\end{array}$ & 0,4 \\
\hline 5 & $\begin{array}{l}\text { Нафта у вигляді плям і плівки, що покрива- } \\
\text { ють значні ділянки поверхні води, які не роз- } \\
\text { риваються під час хвилювання }\end{array}$ & 1,2 \\
\hline 6 & $\begin{array}{l}\text { Поверхня води покрита суцільним шаром } \\
\text { нафти, добре видної під час хвилювання, за- } \\
\text { барвлення темне, темно-коричневе }\end{array}$ & 1,5 \\
\hline
\end{tabular}

Найвищі концентрації нафти зафіксовано переважно у поверхневому, придонному шарах та у прибережній зоні. Основні складники нафти - вуглеводні різних класів - мають низьку розчинність у воді, що знижується зі збільшенням довжини карбонового ланцюга у їх молекулах (Максимюк та ін., 2013).

Інформація про авторів:

Глібовицька Наталія Ігорівна, канд. біол. наук, доцент, кафедра екології. Email: nataly.glibovytska@gmail.com; https://orcid.org/0000-0002-6050-9664

Плаксій Леся Василівна, асистент, кафедра екологіï. Email: ecolesia@ukr.net

Цитування за ДСТУ: Глібовицька Н. І., Плаксій Л. В. Ефективність поглинання нафти сорбентами природного та штучного походження. Науковий вісник НлТУ України. 2019, т. 29, № 6. С. 76-78.

Citation APA: Glibovytska, N. I., \& Plaksiy, L. V. (2019). The efficiency of oil extraction by natural and artificial sorbents. Scientific Bulletin of UNFU, 29(6), 76-78. https://doi.org/10.15421/40290615 
Як нерозчинна у воді суміш, нафта утворює емульсії типу нафта у воді та вода у нафті. Особливу небезпеку становлять агрегати - нафтові грудочки розміром 1-20 мм, оскільки можуть зберігатися довгий час у воді, переміщатися течією та осідати на дні водойми. Агрегати утворюються внаслідок поєднання високомолекулярних вуглеводнів типу смол і асфальтенів у єдину суміш, що є пасткою для водних мешканців - безхребетних та нижчих рослин (Brakorenko \& Korotchenko, 2016).

Для боротьби з нафтовим забрудненням застосовують такі методи (Maksymiuk et al., 2014; Demirbas, 2017):

- механічний - використання обладнання, зокрема сепараторів, для відстоювання забрудненої нафтою води (Padaki, 2015);

- біологічний - розкладання нафтопродуктів мікроорганізмами родів Calanus, Penicillium, Candida, що здатні метаболізувати токсичні компоненти нафти та детоксифікувати їх до нешкідливих сполук. Цей метод, відомий також як біоремедіація, є екологічно безпечним та може використовуватися для відновлення трансформованого під впливом нафти абіотичного середовища (Yatsyshyn \& Hlibovytska, 2016; Glibovytska \& Plaksiy, 2018);

- диспергуючий - використання диспергентів марок ДН-75 та ЕПН-5, які емульгують нафтову плівку до окремих краплин, що піддаються в подальшому біохімічному розкладу;

- сорбуючий - полягає в застосуванні природних або синтетичних пористих матеріалів, здатних ефективно поглинати нафту - вугілля, перліт, дерев'яні ошурки, бентонітові глини, бавовна, торф, полістирол, пінопласт, алюмосилікати, сапропель (Esenkova, 2003; Nabatkyn, 2000). Саме сорбуючий метод $є$ одним 3 найперспективніших способів очищення забруднених нафтою водних ресурсів, оскільки є найменш економічно затратним та найбільш швидким у подоланні проблеми забруднення порівняно з іншими. Тому метою цієї роботи є оцінення ефективності природних i штучних сорбуючих матеріалів у очищенні води від нафтового забруднення.

Матеріали та методи дослідження. Для проведення досліду використовували лабораторну установку (рис. 1). У досліді використовували легку нафту густиною $850 \kappa г / \mathrm{m}^{3}$. Лабораторна установка складається із посудини, заповненої водою, на поверхні якої за допомогою дозатора створюється нафтова пляма певних розмірів. За допомогою дозатора на поверхню плями із бункера подається сорбент. Збірник слугує для зберігання нафти. Секундоміром фіксують час сорбції нафтової плям.

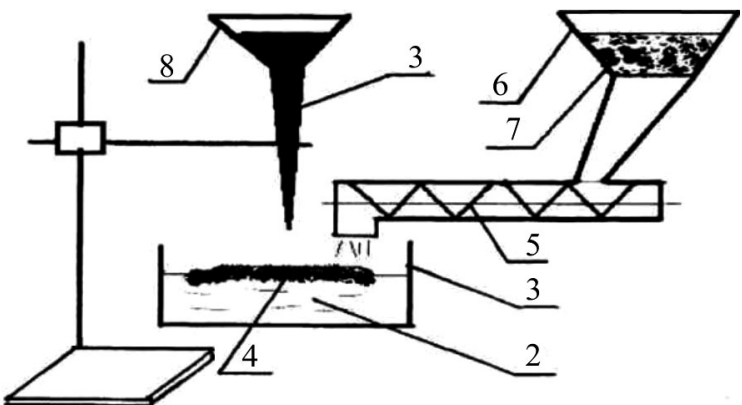

Рис. 1. Схема лабораторної установки: 1) посудина; 2) вода; 3) дозатор нафтопродуктів; 4) нафтова пляма; 5) дозатор сорбенту; 6) бункер сорбенту; 7) сорбент; 8) збірник для нафти чи нафтопродуктів

Для проведення досліду заповнювали дистильованою водою посудину. За допомогою дозатора створювали на поверхні води нафтову пляму розміром 50-70 мм. Дозатором на поверхню плями нафти подавали сор- бент у кількості, яка забезпечує повне покриття плями і одночасно включаємо секундомір. Як сорбенти використовували пінопласт, бавовну, біле та чорне вугілля. Після повного поглинання (сорбції) нафтової плями виключали секундомір, фіксуючи час досліду. Повторність досліду триразова. Статистичне оброблення результатів здійснювали з допомогою програм Excel 2016 та Statistica 6.0 .

Результати дослідження. Найвищу швидкість поглинання нафти виявлено в разі застосування бавовни як сорбенту, найнижчу - за використання чорного вугілля (рис. 2).

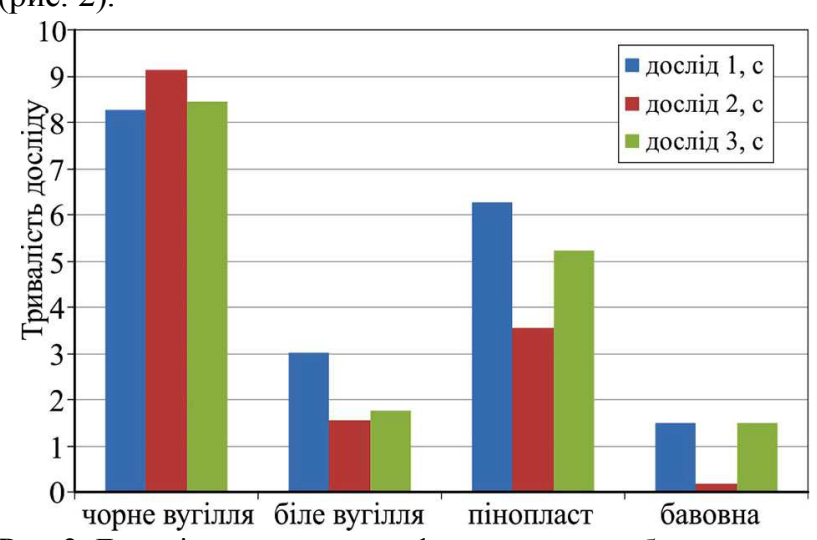

Pис. 2. Динаміка поглинання нафтової плями сорбентами

У разі використання чорного вугілля відбувається процес згущення нафтової плями (табл. 2). Процес сорбції проходить повільно, частина сорбенту з сорбованими нафтопродуктами утворила осад. Під час сорбції чорним вугіллям процес поглинання в середньому відбувається за 1,5 см/с (табл. 3 ).

Табл. 2. Особливості поглинання нафти сорбентами

\begin{tabular}{|c|c|c|c|c|c|c|c|}
\hline \multirow[b]{2}{*}{$\begin{array}{l}\text { № } \\
\text { 3/П }\end{array}$} & \multirow[b]{2}{*}{$\begin{array}{c}\text { Тип } \\
\text { сорбен- } \\
\text { ту }\end{array}$} & \multicolumn{2}{|c|}{ Дослід 1} & \multicolumn{2}{|c|}{ Дослід 2} & \multicolumn{2}{|c|}{ Дослід 3} \\
\hline & & $\begin{array}{c}\text { Час } \\
\text { сор- } \\
\text { бцї̈, с }\end{array}$ & $\begin{array}{c}\text { Ді- } \\
\text { аметр } \\
\text { пля- } \\
\text { ми, см }\end{array}$ & $\begin{array}{c}\text { Час } \\
\text { сор- } \\
\text { бцї̈, с }\end{array}$ & $\begin{array}{c}\text { Ді- } \\
\text { аметр } \\
\text { пля- } \\
\text { ми, см }\end{array}$ & $\begin{array}{c}\text { Час cop- } \\
\text { бції, с }\end{array}$ & $\begin{array}{c}\text { Діаметр } \\
\text { плями, } \\
\text { см }\end{array}$ \\
\hline 1 & $\begin{array}{c}\text { Чорне } \\
\text { вугілля }\end{array}$ & 8,26 & 5,0 & 9,12 & 6,5 & 8,45 & 5,7 \\
\hline 2 & $\begin{array}{c}\text { Біле } \\
\text { вугілля }\end{array}$ & 3,02 & 5,3 & 1,56 & 5,5 & 1,76 & 5,4 \\
\hline 3 & $\begin{array}{c}\text { Піноп- } \\
\text { ласт }\end{array}$ & 6,26 & 5,1 & 3,56 & 7,0 & 5,22 & 5,3 \\
\hline 4 & $\begin{array}{c}\text { Бавов- } \\
\text { на }\end{array}$ & 1,49 & 5,5 & 0,18 & 5,5 & 1,48 & 5,4 \\
\hline
\end{tabular}

Табл. 3. Швидкість поглинання нафтової плями сорбентами

\begin{tabular}{|c|c|c|c|c|}
\hline $\begin{array}{c}\text { № } \\
3 / \Pi\end{array}$ & $\begin{array}{c}\text { Тип сор- } \\
\text { бенту }\end{array}$ & $\begin{array}{c}\text { Середній } \\
\text { час сорбції, } \\
\text { с }\end{array}$ & $\begin{array}{c}\text { Середній ді- } \\
\text { аметр плями, } \\
\text { см }\end{array}$ & $\begin{array}{c}\text { Швидкість погли- } \\
\text { нання нафти сор- } \\
\text { бентами, см/c }\end{array}$ \\
\hline 1 & $\begin{array}{c}\text { Чорне } \\
\text { вугілля }\end{array}$ & $8,61^{ \pm 0,26}$ & $5,73^{ \pm 0,43}$ & 1,5 \\
\hline 2 & $\begin{array}{c}\text { Біле } \\
\text { вугілля }\end{array}$ & $2,11^{ \pm 0,46}$ & $5,40^{ \pm 0,06}$ & 0,39 \\
\hline 3 & Пінопласт & $5,01^{ \pm 0,79}$ & $5,80^{ \pm 0,00}$ & 0,86 \\
\hline 4 & Бавовна & $1,05^{ \pm 0,44}$ & $5,47^{ \pm 0,03}$ & 0,19 \\
\hline
\end{tabular}

Унаслідок використання білого вугілля процес згущення нафтової плями проходить досить інтенсивно, що становить у середньому $0,39 \mathrm{~cm} / \mathrm{c}$. Велика частина сорбенту, що вступив у реакцію, випала в осад.

У разі використання пінопласту відбувається процес адгезії (прилипання до нижньої частини пінопласту). Середній час сорбції нафтової плями - 0,86 см/с. Нафта досить тісно зв'язується з пінопластом, що вказує на перебіг процесу сорбції нафти. 
Унаслідок використання бавовни як сорбенту відбувається процес адгезії, коли нафтова пляма дуже швидко, в середньому $0,19 \mathrm{~cm} / \mathrm{c}$, прилипає до поверхні, після чого можна легко відділити забруднення від поверхні води.

Висновки. Залежно від типу сорбенту, який використовують для очищення води від нафтового забруднення, залежить час і якість поглинання нафти.

Експериментальний дослід показав, що бавовна $\epsilon$ найоптимальнішим варіантом очищення води від нафти. У цьому випадку не потрібно використовувати додаткових уловлювачів осаду. Бавовна найшвидше поглинає нафту. Вода як наслідок залишається чистою. Це найбільш швидкий і результативний спосіб.

Поглинання нафти білим вугіллям здійснюється за незначний час, частина сорбенту випадає в осад. Оскільки не вся маса білого вугілля вступила в контакт 3 нафтою, на поверхні частково залишаються незначні плями.

Пінопласт поглинає нафту за незначний час, однак поступається за ефективністю поглинання білому вугіллю та бавовні - природним матеріалам.

Поглинання нафти чорним вугіллям потребує значного часу та уловлювачів, оскільки вугілля крупно дисперсне і швидко випадає в осад. Цей спосіб очищення води від нафти є найбільш економічно невигідним та потребує тривалого часу для досягнення мети.

\section{Перелік використаних джерел}

Brakorenko, N. N., \& Korotchenko, T. V. (2016). Impact of petroleum products on soil composition and physical-chemical properties. IOP Conf. Series: Earth and Environmental Science, 33, 1-6. https://doi.org/10.1088/1755-1315/33/1/012028

Demirbas, A. (2017). Treatment of contaminated wastewater. Petroleum Science and Technology, 35, 883-889.

Esenkova, N. P. (2003). Tekhnologiia likvidatcii razlivov nefteproduktov na osnove netkanogo sorbenta. Neftianoe khoziaistvo, 2, 9596. [In Russian].
Glibovytska, N. I., \& Plaksiy, L. V. (2018). Methods of water treatment from oil contamination. Ecological education and ecological culture of the population: Materials of the VI International Scientific Conference, (pp. 44-45). Prague, February 25-26.

Kablov, V. F., \& Ioschenko, Yu. P. (2004). Oil spills and the issue of oil removal. Fundamental Research, 6, 64-68.

Maksimov, V. G., Diniak, S. A., \& Diniak, O. V. (2004). Analiz sistemnikh vtrat naftoproduktiv na pidpriemstvakh naftogazovogo kompleksu Ukraini. Ekologiia dovkillia ta bezpeka zhittediialnosti, 5, 41-44. [In Ukrainian].

Maksymiuk, M. R., Chumak, V. L., \& Neshta, T. V. (2000). Adsorbtsiia poverkhnevo-aktyvnykh rechovyn iz stichnykh vod, zabrudnenykh naftoproduktamy. Neftianoe khoziaistvo : materialy XI mizhnarodnoi naukovo-tekhnichnoi konferentsii, 11, 61-63. [In Ukrainian].

Maksymiuk, M. R., Mitskevych, D. I., \& Mitskevych, A. I. (2013). Naftove zabrudnennia poverkhnevykh vod ta shliakhy podolannia yoho naslidkiv. Naukovi pratsi. Tekhnohenna bezpeka. Konferentsii "AVIA-2013", NAU, (pp. 21-23). [In Ukrainian].

Nabatkyn, A. N. (2014). Prymenenye, (Vol. 221(233), pp. 37-40). Mykolaiv: Vyd-vo ChDU im. Petra Mohyly. [In Ukrainian].

Padaki, M. (2015). Membrane technology enhancement in oil-water separation. A review. Desalination, 357, 197-207.

Plaksii, L. V. (2016). Metodolohiia otsiniuvannia poverkhnevykh vod v mistsiakh vplyvu obiektiv naftoprovidnoho transportu. Ekolohichna bezpeka ta zbalansovane resursokorystuvannia, 2(14), 5 p. Ivano-Frankivsk: IFNTUNH. [In Ukrainian].

Pogharnitskaya, O. V., et al. (2016). Treatment of petroleum-contaminated water resources: modern techniques. IOP Conf. Series: Earth and Environmental Science, 43, 1-6. https://doi.org/10.1088/1755$1315 / 43 / 1 / 012026$

Tsibulnikova, M. R. (2015). Economic assessment of environmental impact in the course of oil field development and production. IOP Conf. Series: Earth and Environmental Science, 27, 1-5. https://doi.org/10.1088/1755-1315/27/1/012076

Vladimirov, V. A. (2014). Oil spills: causes, scales, effects. Civil safety strategy: issues and research, 1, 217.

Yatsyshyn, T. M., \& Hlibovytska, N. I. (2016). Vplyv naftohazovydobutku na dovkillia i perspektyvy fitoindykatsii ta fitoremediatsii tekhnohennotransformovanykh terytorii. Ekolohichna bezpeka ta zbalansovane resursokorystuvannia, 1, 22-29. [In Ukrainian].

\section{THE EFFICIENCY OF OIL EXTRACTION BY NATURAL AND ARTIFICIAL SORBENTS}

The global environmental problem of water resources contamination by oil and methods of solving it are considered. The efficiency of simple and accessible methods of oil-contaminated water purification is investigated. The economic benefit from the use of the sorbent method for solving the problem in comparison with the mechanical and dispersive method is revealed. The mechanical method of water purification from oil involves the use of expensive equipment. The dispersant method involves two successive stages of combating pollution of water resources with petroleum products. This, in turn, requires additional material and human resources, as well as a long period of time. The biological method of water purification from oil requires careful research, since organisms-remindants of oil can behave differently in their habitats and at a favourable level of life - to push out other indigenous species or to detect invasive effects on the ecosystem. The sorbing method is least cost-effective and ecologically friendly, since it involves the use of a wide range of sorbents of oil. The promise of this method is the availability of some natural and artificial materials that can be used as sorbents of oil. We have analyzed the practical value, advantages and disadvantages of natural and artificial sorbents of oil, which are widely used in various industries and national economy. The maximum absorption capacity of cotton is identified as a natural material that quickly absorbs oil components and does not require the use of additional resources to fight water contamination. Therefore, we recommend introducing the use of cotton as an environmentally safe and costeffective material in solving the problem of water pollution with oil and petroleum products. We have found natural charcoal absorbent to be inefficient in comparison with other methods of water purification from oil and to require a long period of time and additional pollution traps, which is economically unprofitable. Synthetic polymer foam and white coal absorb oil in a short time, but in the latter case, small spots remain on the surface of the water. Therefore, the effectiveness of oil absorption by natural and synthetic materials, one can distinguish the following series of investigated materials: black coal $\rightarrow$ foam $\rightarrow$ white coal $\rightarrow$ cotton.

Keywords: oil; pollution; water resources; purification; methods; sorbents. 